With birds and flowers gone we can now anticipate many hours of pleasure in the museum. The old and the new cases, the wild-life arrangement, the herbarium, all make hours spent there fly like wings:

But our walks still hold beauty. We take more note: of the character of the bare old trees - their beauty of line; the good earth rests in peace bathed in sunshine or sunset glory. Sunrise will delight as always as it makes a pattern of silver lace on our shimmering trees.

As I think of it my wee granddaughter rushes in - a snowflake caught in her mitten - "Look Gram - the star of Bethlehem" - winter is here.

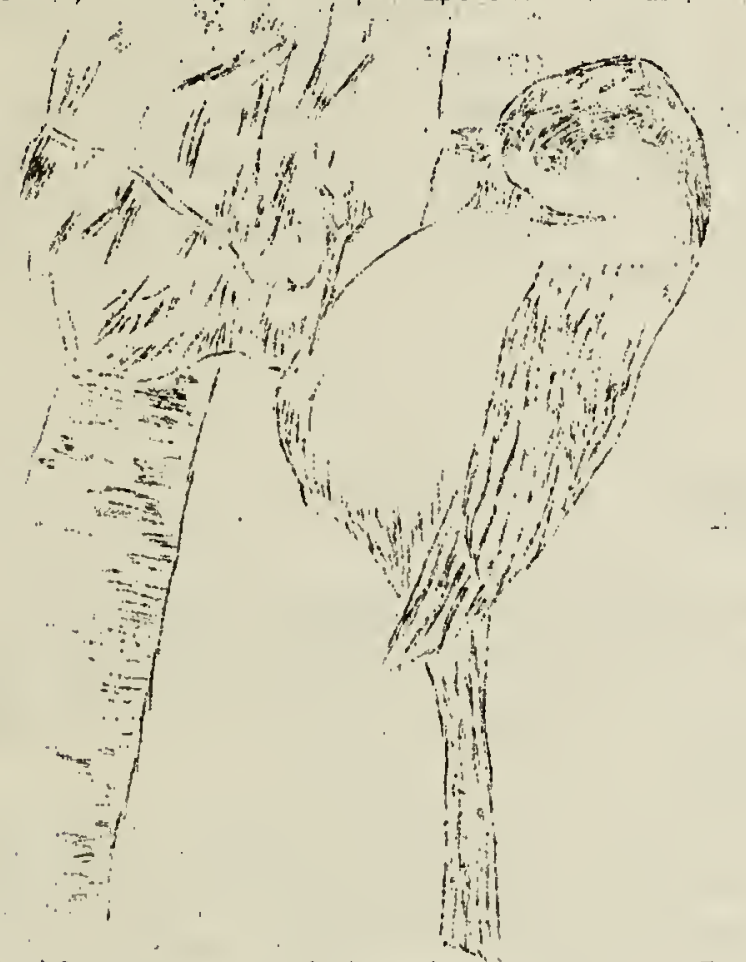

\title{
CHICKADEES
}

Although many birds which customarily show up in the Grenfell area were, because of the hot dry summer, conspicuous by their absence, the Chickadees, Barn Swallows and Orioles were back in goodly numbers, according to a report received from Nirs. F. Bilsbury.

Among the "black-caps" several were noticed that were red-backed and Mrs. Bilsbury was puzzled as to their identity.

It. would seem that the Hudsonian Chickadee, a visitor from the north, had dropped in on its cousin, asking for a share of the local bird's suet. But if this were so it would be an interesting record for the prairie Bo early in the season. In fact, according to Mr. Bard, of the Provincial Museum, none of these birds have before been reported as having been seen on the prairie in summer. It is quite possible that they may be the common chickadee which very often vary in color.

Among other summer visitors Mrs. Bilsbury was fortunate enough to Identify a Says Phoebe, a bird which she had not seen before. A pair of Blue Herrons visited local dugouts and spent the summer in and around the district. A pair of Kingbirds returned to nest in the trees about the house for the fourth consecutive year.

"I have notioed that a pair of Bluebirds returned this fall with a brood of nine. This seems rather a large number for one pair of birdis. Are there any records of their raising two broods in one season?"

\section{PRAIRIE CHICKENS}

Chas, Leach, Regina

Mr. Leach is both pleased and amazed at the remarkable comeback of the Prairie Chicken in the Regina district.

On Thanksgiving Day, October 10, he saw at least three hundred in an area some fifteen miles north-east of the city. One large flock had congregated on the side of a hill, as if participating in one of their dances. "The noise they were making could be heard distinctly over half a mile away. 


\section{A STARLING AT IANGBANK}

Mrs. G. M. Hewson writes that she is very well pleased with the issues of the BLUE JAY and adds that her family are all interested in natural history and enjoy anything that will give them more accurate information of: our birds, plants and animals.

She describes in detail the appearance of a bird about the size of a blackbird which took refuge in the stable during the evening of the first day of snow.

Mrs. Elizabeth B. Flock, a Regina authority of prairie birds, feels quite sure that the bird described is a Starling. The crest shown in the picture in "Birds of Western Canada" is not always apparent. The white outer tall feathers are conspicuous in spring plumage, but may not be present later in the year. Mrs. Flock thinks that this bird only fits the description given, which she describes briefly as a stubby-tailed blackbird with a long, yellowish bill.

\section{BIRDING IN THE GARDEN Elizabeth B. Flock}

Birding in even a small city garden can prove a surprisingly rewarding pastime. Strange visitors from marshland or northern forests may stop for a brief rest. It will prove interesting to keep a House list of all spepies seen together with the date to refresh the memory.

A few of our own experiences include a sora rail that found its way Into the front yard last spring. where it was concealed so effectually that I almost stepped on the bird before it took off in a gangling:flight across the street. Another dweller in the wet places, a water-thrush, spent, some time bobbing away among the shrubs looking for food. An ovenbird with its amusingly sedate walk was seen up and down the garden paths for a few days. Upon one occasion I was astonished to look up into our cottonwood and meet the intent stare of a long-eared owl.

Shortly before frost a ruby-throated humingbird darted straight for a few late flowers of scarlet lychnis, ignoring all the other blossoms and. thus showing its preference for red ones. It did deviate for a moment over some blue Chinesedelphiniums before flying straight across the garden to another small patch of lychnis. The same procedure was repeated at about the same time two days later which seemed to indicate that both visits were made by one bird.

Two thrushes in the garden late in the season suggested they were hermits, when one bird stopped obligingly with its back in a patch of sunlight where the reddish tail showed clearly. Turning, the dark breast spots were conspicuous. About the same time a white-throated sparrow scurried through the asparagus, stopping now and then to scratch diligently. Although I was sitting quietly only a few feet away, the bird seemed indifferent to my presenoe.

More chickadees come to town in the autumn and winter some years than others. This seems to be a chickadee year for us. The first one was alone on a lilac bush. When it caught sight of the bird bath it flew at onse to perch on the side for repeated sips of water. Next, two spent as many days golng over the cottonwood with minute care while they kept up a constant chatter with an occasional change to the clear "phoebe" whistle of spring. $\dot{A}$ fourth chickadee made a quick survey of the premises and was gone.

Another visitor to the cottonwood was a golden-crowned kinglet too high up to recognize until it dropped into a l1lac bush close by where the sun 